\title{
Pengangkatan Benda Asing dengan Metode Coelio-Plastronotomi pada Kura-Kura Pardalis (Stigmochelys pardalis)
}

\author{
Foreign Body Removal Surgery using Coelio-Plastronotomy in A Pardalis Tortoise \\ (Stigmochelys pardalis)
}

\author{
Nofan Rickyawan $^{1 *}$, Syavira Ekhdiasmara ${ }^{2}$, Yulinar Risky Karaman², Ricky Kartika², \\ Ulvi Hudriyah ${ }^{2}$ \\ ${ }^{1}$ Laboratorium Klinik Hewan, Bidang Ilmu Bedah dan Radiologi, Fakultas Kedokteran Hewan, Universitas \\ Brawijaya, ${ }^{2}$ Rumah Sakit Hewan Pendidikan, Universitas Brawijaya \\ *Corresponding author: nofanvet@ub.ac.id
}

\begin{abstract}
Abstrak
Seekor kura-kura Pardalis jantan, berumur sekitar 2 tahun dengan berat badan $1.65 \mathrm{~kg}$ memiliki gejala penurunan aktivitas, anoreksia dan tidak defekasi sejak 7 hari sebelumnya. Diagnosa yang diperoleh dari hasil anamnesa, pemeriksaan fisik dan radiografi adalah obstruksi saluran gastrointestinal karena benda asing. Coelioplastronotomi merupakan tindakan pembedahan untuk mengakses organ di rongga coelomic dengan cara melakukan ostetomi pada plastron. Induksi anestesi menggunakan ketamine $10 \mathrm{mg} / \mathrm{kg} \mathrm{BB}$, medetomidine 0.3 $\mathrm{mg} / \mathrm{kg} \mathrm{BB}$ dan dilanjutkan dengan isoflurane $2 \%$ untuk tetap mempertahankan dalam kondisi teranestesi. Pemotongan plastron menggunakan gergaji besi sirkuler dengan sudut kemiringan $45^{\circ}$ dan disertai irigasi $\mathrm{NaCl}$ $0.9 \%$. Membran coelomic diinsisi dengan menghindari vena abdominalis untuk mengaskes rongga coelomic. Enterotomi dilakukan untuk mengambil benda asing yang berada di lumen kolon. Fiksasi plastron menggunakan lem epoksi dengan sebelumnya menutup fisura antar fragmen dengan selotip. Esofagostomi pemasangan selang pakan dilakukan untuk tetap dapat memberikan nutrisi, terapi cairan dan obat ketika kondisi kritis. Penggunaan penghangat selama proses anestesi, operasi dan pemulihan untuk mencegah hipotermia, mengoptimalkan kerja obat dan memaksimalkan kesembuhan luka. Enrofloxacin $5 \mathrm{mg} / \mathrm{kg} \mathrm{BB} /$ hari, ketoprofen $2 \mathrm{mg} / \mathrm{kg} \mathrm{BB} / \mathrm{hari}$, terapi cairan dan nutrisi diberikan untuk membantu pemulihan pasca operasi.
\end{abstract}

Kata kunci: kura-kura Pardalis, coeliotomi, plastronotomi, enterotomi

\section{Abstract}

A male Pardalis tortoise, about 2 years old weighing $1.65 \mathrm{~kg}$ had symptoms of albeviation activity, anorexia and no defecation along 7 days. Diagnosis performed by the results of anamnesa, physical examination and radiography in gastrointestinal tract obstruction due to foreign body. Coelio-plastronotomy is a surgery to access organs in the coelomic cavity by performing a plastron ostetomy. Ketamine $10 \mathrm{mg} / \mathrm{kg} \mathrm{BB}$, medetomidine $0.3 \mathrm{mg} / \mathrm{kg} \mathrm{BB}$ used for anesthesia induction and isoflurane $2 \%$ used to maintain anesthetized. Plastronotomy performed using circular iron saw with a slope angle of $45^{\circ}$ and $0.9 \% \mathrm{NaCl}$ irrigation. Incision on coelomic membrane by avoiding the abdominal vein to access coelomic cavity. Enterotomy used to remove foreign bodies in the colons lumen. Plastron fixation used epoxy by previously covering the fissure between fragments with waterproof tape. Esophagostomy tube placement was performed to keep a provide nutrition, fluid therapy and medication in the critical condition. Heating pad used during anesthesia, surgery and recovery to prevent hypothermia, optimize drug action and maximize wound healing. Enrofloxacin $5 \mathrm{mg} / \mathrm{kg}$ $B W /$ day, ketoprofen $2 \mathrm{mg} / \mathrm{kg}$ BW/day, fluid and nutritional therapy were given to help postoperative recovery.

Keywords: Pardalis tortoise, coeliotomy, plastronotomy, enterotomy

\section{PENDAHULUAN}

Kura-kura Pardalis (Stigmochelys pardalis) termasuk ke dalam genus Geochelone berukuran relatif besar, bersifat diurnal, ovipar, memiliki habitat semak belukar semi gurun pasir hingga padang rumput, sabana dan hutan (UNEP-WCMC, 2014). Kura kura Pardalis salah satu jenis kura-kura darat (Tortoise) dan umumnya herbivora yang memakan hijauan 
(95\%) dan buah (5\%) (Rossi, 2006b). Menurut O’Malley (2005), kura-kura memiliki bentuk mulut seperti paruh pendek dengan tepi yang tajam dan tidak bergigi sehingga tidak memiliki kemampuan mengunyah dan memilah pakan. Kura-kura juga memiliki kebiasaan memakan benda asing yang disebut geofagi. Benda asing yang tertelan dapat menyebabkan kerusakan dinding saluran pencernaan, mengganggu penyerapan nutrisi bahkan obstruksi yang berakibat kematian (Yamgar et al., 2019).

Enterotomi adalah suatu tindakan penyayatan usus baik usus halus maupun usus besar yang mengalami obstruksi atau karena adanya benda asing berupa tulang yang keras, kaca, kawat, besi, seng dan rambut atau kemungkinan adanya gangrene pada usus (Fossum, 2019; Guiffrida dan Brown, 2018). Kura-kura memiliki anatomi yang berbeda dengan mamalia, sehingga prosedur operasi yang dilakukan berbeda. Coeliotomi adalah metode untuk mengakses organ di rongga coelomic pada reptil seperti jantung, paru, hepar dan saluran pencernaan (Mader et al., 2006). Tindakan ini bertujuan untuk berbagai macam hal seperti eksplorasi, implantasi dan biopsi (Alworth et al., 2011). Khusus coeliotomi pada kura-kura, metode yang dilakukan adalah dengan ostetotomi pada plastron atau plastronotomi (Knotek dan Wilkinson, 2018; Amat et al., 2012; Mader et al., 2006). Operasi pengangkatan benda asing pada saluran pencernaan, reseksianastomosis dan anastomosis atresia kolorektal dapat dilakukan pada reptil dengan memiliki tingkat keberhasilan yang baik (Alworth et al., 2011).

\section{METODE}

\section{Alat dan Bahan}

Gergaji besi sirkuler, satu set instrumen untuk laparotomi, mesin anestesi inhalasi, endotrakeal tube, selang pakan, isoflurane, ketamine $\mathrm{HCl} 10 \%$, medetomidine $0.1 \%$, cairan infus $\mathrm{NaCl} 0.9 \%$, cairan infus ringer laktat, selotip, lem epoksi, kawat kasa, benang absorbable berjenis polyglactin ukuran 4.0 dengan jarum bulat.

\section{Anamnesa dan Pemeriksaan Fisik}

Seekor kura-kura Pardalis berumur sekitar 2 tahun, berjenis kelamin jantan dengan berat badan $1.65 \mathrm{~kg}$ memiliki gejala penurunan aktivitas, anoreksia dan tidak defekasi sejak 7 hari sebelumnya. Pemilik menyampaikan bahwa kura-kura diduga memakan bebatuan saat makan di taman. Hasil pemeriksaan fisik ditemukan kura-kura dalam kondisi lemah, dehidrasi dan tampak mata cekung serta berair.

\section{Pemeriksaan Radiografi}

Pemeriksaan radiografi dilakukan untuk mengetahui ada tidaknya abnormalitas di dalam tubuh sehingga dapat membantu peneguhan diagnosa. Berdasarkan hasil radiografi, terlihat adanya bentukan yang bersifat radiopaque merata, tepi halus dan rata, berukuran sekitar 1-2 $\mathrm{cm}$, berjumlah sekitar 5-6 dan berlokasi di area abdomen (Gambar 1). Apabila dikorelasikan dengan keterangan dari pemilik, dipastikan bahwa bentukan tersebut adalah bebatuan yang dimakan oleh kura-kura. Tindakan operasi enterotomi dengan metode coelio-plastronotomi menjadi pilihan utama untuk mengeluarkan benda asing tersebut. Ukuran, jumlah dan lokasi benda asing berdasarkan hasil radiografi diukur untuk menentukan lokasi dan luasan plastron yang akan dipotong.

\section{Tindakan Operasi}

Karapas dan plastron kura-kura dibersihkan menggunakan chlorhexidin $0.2 \%$ dan disterilkan menggunakan alkohol 70\%. Area plastron diukur dan diberi tanda menggunakan tinta sesuai dengan ukuran dan lokasi benda asing berdasarkan hasil radiografi. Anestesi menggunakan injeksi kombinasi ketamine 10 $\mathrm{mg} / \mathrm{kg} \mathrm{BB}$ dan medetomidine $0.3 \mathrm{mg} / \mathrm{kg}$ secara intramuskular pada bagian femoral. Intubasi dilakukan setelah kura-kura teranestesi. Cara intubasi adalah dengan memasang endotrakeal tube ke ke dalam glotis yang terletak di bagian dasar rongga mulut kura-kura. Endotrakeal tube kemudian dihubungkan ke mesin anestesi inhalasi. Dosis isoflurane yang digunakan adalah 
$2 \%$ untuk mempertahankan kura-kura tetap dalam kondisi teranestesi.

Kura-kura diposisikan rebah dorsal di atas meja operasi yang sudah diberi alas penghangat dan disekitar tubuhnya diberi penahan berupa botol infus untuk mempertahankan posisi tersebut tetap stabil selama operasi. Operasi diawali dengan melakukan plastronotomi sesuai dengan garis tanda yang dibuat. Pemotongan dilakukan dengan kemiringan $45^{\circ}$ dan disertai irigasi $\mathrm{NaCl} 0.9 \%$. Pemotongan menggunakan gergaji besi sirkuler dan menghindari perlukaan jaringan di dalam rongga coelomic. Setelah terpotong, fragmen diangkat perlahan menggunakan bantuan pinset dan blade scalpel untuk memisahkan beberapa jaringan yang masih menempel. Fragmen plastron yang sudah terlepas dimasukkan ke dalam larutan $\mathrm{NaCl}$ $0.9 \%$ steril. Membran coelomic yang berada di bawah plastron disayat arah kranio-kaudal tepat di tengah diantara sepasang vena abdominalis. Pembuluh darah tersebut harus dihindari dan jangan sampai terpotong. Pasca rongga coelomic terbuka, dilakukan eksplorasi untuk menemukan lokasi benda asing.

Enterotomi dilakukan pada kolon tempat benda asing ditemukan. Jahitan antar jaringan untuk memfiksasi posisi kolon agar tetap stabil dan peletakkan kasa steril di sekitarnya untuk mencegah kontaminasi isi kolon ke dalam rongga coelomic. Kolon disayat sepanjang $2 \mathrm{~cm}$ untuk mempermudah pengambilan benda asing. Penutupan kolon dilakukan setelah benda asing terambil semua. Penjahitan kolon dilakukan dengan jahitan pola sederhana tunggal menggunakan benang absorbable berjenis polyglactin ukuran 4.0. Rongga coelomic kemudian dibersihkan dan dibilas menggunakan larutan $\mathrm{NaCl}$ 0,9\% dari debris plastron maupun kontaminan isi kolon. Membran coelomic ditutup menggunakan jahitan pola sederhana tunggal dengan benang absorbable berjenis polyglactin ukuran 4.0. Fragmen plastron diletakkan kembali sesuai dengan posisi awal kemudian selotip ditempelkan pada fisura antar fragmen plastron. Kawat kasa diletakkan di atasnya dan lem epoksi dituangkan serta diratakan untuk menutupi plastron khususnya area plastronotomi. Lem epoksi didiamkan selama 10-15 menit untuk dapat kering dan mengeras.

Esofagostomi dilakukan untuk memasang selang pakan dari bagian lateral leher kura-kura ke dalam lumen esofagus. Tindakan ini dilakukan ketika kondisi kura-kura masih teranestesi. Sisa selang diarahkan ke arah dorsal dan difiksasi pada karapas menggunakan selotip untuk mempermudah pemberian pakan, cairan maupun obat. Pasca operasi, kura-kura diletakkan di tempat yang diberi alas dan lampu penghangat. Pengobatan diberikan antibiotik enrofloxacin dosis $5 \mathrm{mg} / \mathrm{kg}$ BB/hari dan analgesik ketoprofen dosis $2 \mathrm{mg} / \mathrm{kg} \mathrm{BB} / \mathrm{hari}$. Kedua obat tersebut diinjeksikan secara intramuskular pada bagian femoral selama 5 hari. Terapi cairan menggunakan ringer laktat dosis $10 \mathrm{ml} / \mathrm{kg} \mathrm{BB} /$ hari selama 3 hari dengan rute injeksi sub kutan pada regio axillaris. Pakan diberikan jus kombinasi sawi, apel dan $\mathrm{NaCl}$ $0.9 \%$ sebanyak $5 \mathrm{ml}$ yang diberikan 2 kali sehari dan dimasukkan langsung ke lambung melalui selang pakan (Gambar 2).

\section{HASIL DAN PEMBAHASAN}

Hasil anamnesa, pemeriksaan fisik dan radiografi pada pasien, mengindikasikan adanya abnormalitas pada saluran pencernaan. Bebatuan, pasir dan kerikil sering ditemukan pada saluran gastrointestinal kura-kura. Apabila terdapat dalam volume yang besar, dapat menyebabkan konstipasi maupun obstruksi (Silverman, 2006). Menurut Rodriguess et al. (2015), kasus obstruksi intestinal pada kura-kura dapat menimbulkan gejala klinis akibat toksemia seperti apatis, tidak mau berjalan, membran mukosa mata kemerahan serta berair. Hasil radiografi menunjukkan adanya benda asing berupa batuan dan bukan kalkuli yang sering diderita jenis kura-kura darat. Kalkuli biasanya memiliki radiopasitas yang tinggi, bentuk yang relatif bulat dengan struktur dan tepi yang ireguler. Batuan dapat ditemukan berjumlah satu atau lebih dengan opasitas yang tinggi dan merata, bentuk bervariasi dan berlokasi di lambung atau intestinal yang mengalami 


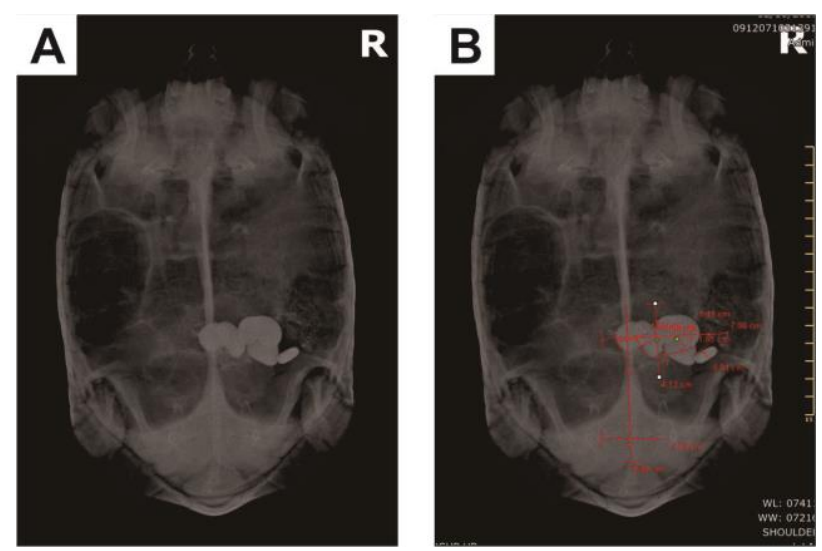

Gambar 1. Hasil radiografi posisi Dorso Ventral (DV). (A) Tampak bentukan radiopaque di area abdomen; (B) Tampak ukuran dan jumlah benda asing
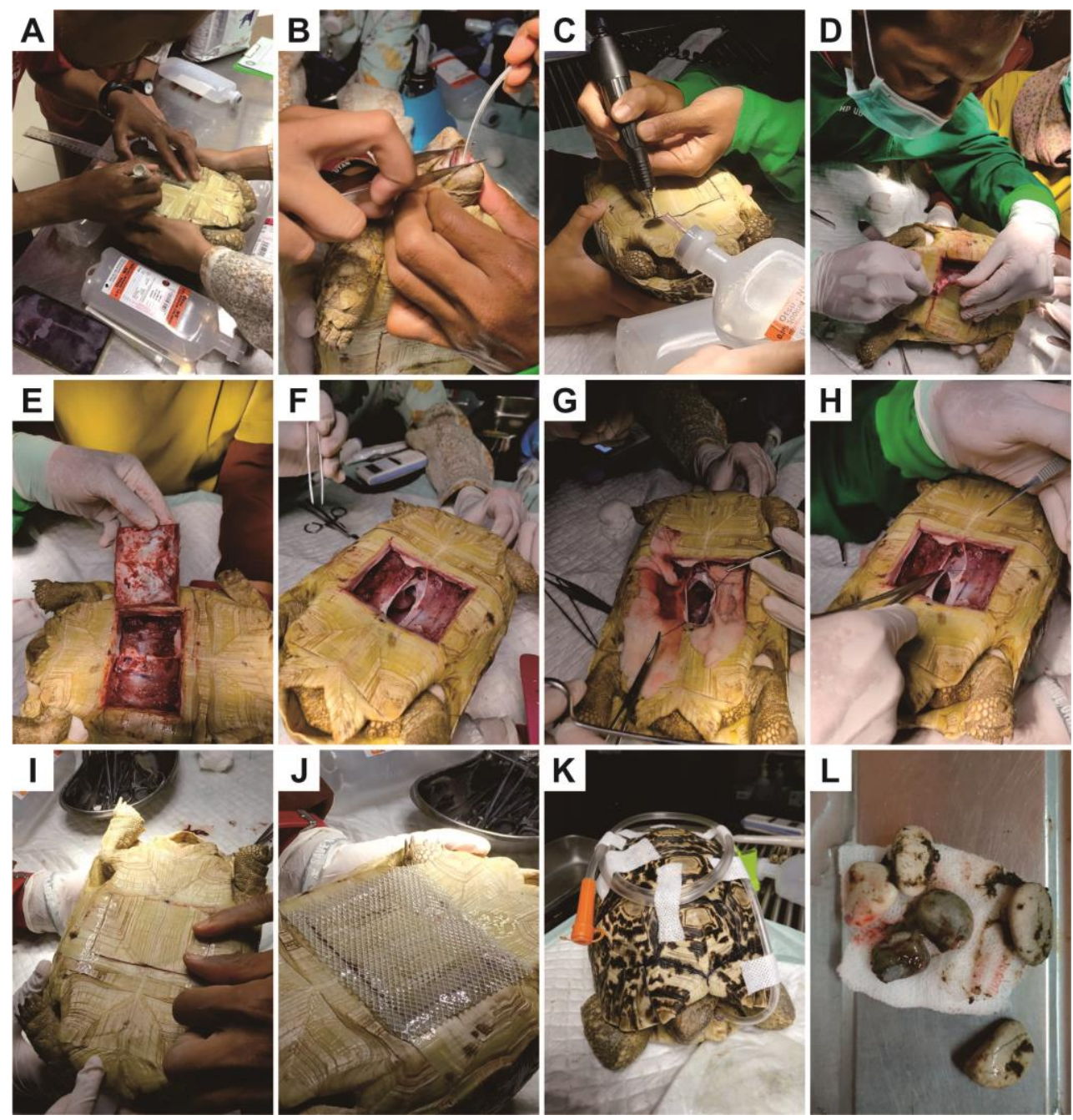

Gambar 2. Tindakan operasi. (A) Pembuatan garis bantu plastronotomi berdasarkan hasil radiografi; (B) Pemasangan endotrakeal tube pasca induksi anestesi; (C) Plastronotomi dengan gergaji besi sirkuler disertai irigasi $\mathrm{NaCl} 0.9 \%$; (D) Pemisahan fragmen plastron dengan jaringan di bawahnya; (E) Pengangkatan fragmen plastron sampai menemukan membran coelomic; (F) Insisi membran coelomic di medial; (G) Enterotomi; (H) Penjahitan membran coelomic; (I) Penempelan selotip di fisura antar fragmen plastron; (J) Pemasangan kawat kasa dan lem epoksi; (K) Pasca pemasangan selang pakan dengan esofagostomi; (L) Enam butir batu yang berhasil diangkat 
abnormalitas pencernaan (Farrow, 2009; Silverman, 2006). Tindakan operasi menjadi pilihan utama untuk kelangsungan hidup pasien (Mader et al., 2006).

Kombinasi ketamine $10 \mathrm{mg} / \mathrm{kg}$ BB dengan medetomidine $0.3 \mathrm{mg} / \mathrm{kg}$ BB sering digunakan sebagai agen anestesi pada semua jenis reptil (Klaphake et al., 2018). Induksi anestesi dilakukan untuk membantu pemasangan endotrakeal tube. Pemasangan endotrakeal tube sangat direkomendasikan pada semua pasien reptil untuk memastikan saluran nafas tetap terbuka, mencegah aspirasi dan sebagai akses untuk memberikan ventilasi dengan tekanan positif secara berkelanjutan ketika kondisi teranestesi (Schumacher dan Yelen, 2006). Dosis isoflurane yang dapat diberikan adalah 2-3\% untuk tetap mempertahankan kura-kura dalam kondisi teranestesi (Klaphake et al., 2018; Schumacher dan Yelen, 2006). Isoflurane sangat direkomendasikan pada kura-kura dan aman untuk tindakan operasi walaupun diperlukan anestesi injeksi seperti ketamine yang dikombinasikan dengan transquilizer untuk induksi (Rodrigues et al., 2015; Schumacher dan Yelen, 2006).

Penentuan lokasi dan luasan plastronotomi harus dibuat dengan tepat untuk memberikan akses pada organ target sehingga mempermudah proses operasi. Apabila ukuran benda asing atau kalkuli besar, maka pemotongan plastron semakin luas (Mader et al., 2006). Pemotongan pada plastron dilakukan dengan kemiringan $45^{\circ}$ dan disertai irigasi menggunakan $\mathrm{NaCl}$ 0,9\%. Irigasi bertujuan menghilangkan panas yang dapat menyebabkan nekrosis jaringan plastron dan meminimalkan debu pada saat proses pemotongan plastron (Mader et al., 2006). Pemotongan oblique pada plastron harus dilakukan untuk membantu fragmen yang diangkat dapat ditempelkan kembali (Rodrigues et al., 2015).

Saluran intestinal kura-kura yang pendek dengan mesenterium yang juga pendek dan menempel pada membran pleura, membuat tindakan enterotomi lebih sulit dilakukan dibandingkan pada mamalia. Enterotomi dilakukan dengan posisi intestinal tetap berada di dalam rongga coelomic dengan keterbatasan visualisasi pada lokasi dan akses menuju intestinal (Knotek dan Wilkinson, 2018; Mader et al., 2006). Penggunaan kasa steril di sekitar intestinal yang akan diinsisi dapat mencegah kontaminasi dari isi intestinal ke dalam rongga coelomic akibat kebocoran yang tidak terduga. (Alworth et al., 2011). Menurut Zaher et al. (2012), struktur saluran pencernaan termasuk kolon pada reptil hampir sama dengan vertebrata. Oleh karena itu, tehnik penutupan luka dan jenis benang yang digunakan sama dengan yang diaplikasikan pada mamalia. Penutupan intestinal pasca enterotomi menggunakan pola jahitan sederhana tunggal yang menembus semua lapisan intestinal dengan jarak antar jahitan sekitar 2-3 $\mathrm{mm}$ dan menggunakan benang absrobable seperti polydioxanone, polyglycinate atau polyglecaprone dengan jarum ujung bulat (Fossum, 2019). Sebelum dilakukan penutupan, rongga coelomic dibersihkan dan dibilas menggunakan $\mathrm{NaCl}$ 0,9\%. Pembersihan dan pembilasan menggunakan $\mathrm{NaCl} 0,9 \%$ hangat bertujuan untuk memastikan tidak ada debris plastron dan kontaminasi isi intestinal yang tertinggal di dalam rongga coelomic (Mader et al., 2006).

Proses perekatan dan bahan perekat yang digunakan untuk menempelkan kembali plastron sangat menentukan keberhasilan operasi. Perekat yang dapat digunakan untuk menahan fragmen plastron seperti resin autopolimer, polimetilmetakrilat, epoksi, kasa fiber, plat besi dan sekrup ortopedik (Girolamo dan Mans, 2016; Rodrigues et al., 2015; Alworth et al., 2011; Mader et al., 2006). Penggunaan perekat tersebut bertujuan untuk melindungi dan mengimobilisasi fragmen plastron sehingga dapat membantu keberhasilan pemulihan pasca operasi (Rodrigues et al., 2015). Komplikasi yang sering terjadi pasca coelio-plastronotomi adalah kesembuhan plastron yang buruk, dehisensi dan coelomitis (Girolamo dan Mans, 2016). Hal ini disebabkan karena adanya infeksi atau jaringan plastron mengalami nekrosis akibat panas pada saat proses pemotongan atau fisura antar fragmen plastron tertutup oleh perekat 
yang menyebabkan terhambatnya proses penyambungan (Girolamo dan Mans, 2016; Amat et al., 2012; Mader et al., 2006). Oleh karena itu, penggunaan selotip kedap air bertujuan untuk menutup aposisi fragmen plastron agar tidak terkena perekat. Perekat berupa lem epoksi tetap dibiarkan selama 6-24 bulan dan untuk menilai tingkat kesembuhan plastron dapat dipastikan menggunakan radiografi (Girolamo dan Mans, 2016; Alworth et al., 2011).

Esofagostomi adalah tindakan operasi untuk membuat lumen pada esofagus (Fossum, 2019). Esofagostomi dilakukan untuk tetap dapat memberikan nutrisi dan obat-obatan ketika dalam kondisi kritis atau ketika pemberian pakan lewat mulut sulit dilakukan karena ada kerusakan di area mulut dan kepala (Kyles dan Huck, 2018; Girolamo dan Mans, 2016; Chitty dan Raftery, 2013). Selang pakan dapat terpasang hingga 1-2 minggu setelah nafsu makan kura-kura kembali normal (Mitchell, 2006). Penggunaan penghangat bertujuan untuk mencegah hipotermia pada saat proses anestesi, operasi dan pemulihan. Reptil termasuk ke dalam hewan poikiloterm, yang berarti suhu tubuhnya tergantung dengan suhu lingkungan dan setiap spesies memiliki rerata suhu optimalnya yang mendukung semua sistem organ bekerja efektif (Perpinan, 2018; Rossi, 2006a). Metabolisme obat anestesi di dalam tubuh dan fungsi organ, sangat bergantung pada suhu lingkungan. Oleh karena itu, penting untuk menjaga reptil sesuai dengan suhu idealnya (Perpinan, 2018). Suhu lingkungan yang tidak ideal dapat memperlambat proses kesembuhan dan menurunkan sistem imun (McArthur dan Divers, 2004).

Pemberian antibiotik ketika melakukan tindakan operasi harus dilakukan, karena stress akibat anestesi dan pembedahan dapat berpotensi menimbulkan infeksi alami atau iatrogenik (Mader et al., 2006). Persiapan operasi kura-kura dalam kondisi steril juga cukup sulit, karena struktur kulit yang kasar dan memiliki cangkang (McArthur dan Divers, 2004). Enrofloxacin merupakan pilihan antibiotik yang sering digunakan pada semua jenis reptil dan dosis yang disarankan 5-10 mg/kg BB/hari (Klaphake et al., 2018). Antibiotik ini sering digunakan untuk terapi infeksi pada reptil karena efektif untuk bakteri gram positif dan gram negatif (Mitchell, 2006). Rasa sakit, stress dan ketidaknyamanan memiliki korelasi yang erat, sehingga manajemen pengelolaan nyeri sangat diperlukan pada reptil khususnya dalam tindakan pembedahan baik pre, peri- maupun pascaoperasi (Mader et al., 2006). Salah satu analgesik yang sering diberikan adalah ketoprofen dengan dosis $2 \mathrm{mg} / \mathrm{kg} \mathrm{BB} / \mathrm{hari}$ (Klaphake et al., 2018). Terapi cairan yang direkomendasikan sebanyak $10-40 \quad \mathrm{ml} / \mathrm{kg}$ $\mathrm{BB} /$ hari menggunakan cairan kristaloid isotonis $\mathrm{NaCl}$ 0.9\% atau ringer laktat (Herrin, 2018). Salah satu rute yang disarankan adalah subkutan pada regio inguinalis atau axillaris (Mitchell, 2006).

\section{KESIMPULAN}

Enterotomi untuk mengangkat benda asing pada kura-kura Pardalis dapat dilakukan dengan metode coelio-plastronomi dan harus didukung dengan prosedur esofagostomi, penggunaan penghangat, terapi antibiotik, analgesik dan terapi cairan untuk membantu kesembuhan.

\section{UCAPAN TERIMA KASIH}

Penulis mengucapkan terima kasih kepada pimpinan dan staff Rumah Sakit Hewan Pendidikan, Universitas Brawijaya, Mahasiwa Program Pendidikan Profesi Dokter Hewan Fakultas Kedokteran Hewan, Universitas Brawijaya Gelombang 12 dan 13.

\section{DAFTAR PUSTAKA}

Alworth, L.C., Hernandez, S.M., Divers, S.J. 2011. Laboratory Reptile Surgery: Principle and Technique. JAALAS., 50(1), 1-16.

Amat, A.C., Gabriel, B., Chee, N.W. 2012. Cystic Calculi Removal in African spurred Tortoise (Geochelone sulcata) Using 
Transplatstron Coeliotomy. Vet. World., 5(8), 489-492.

Chitty, J., Raftery, A. 2013. Essentials of Tortoise Medicine and Surgery. Wiley Blackwell, pp: 181-184.

Farrow, C.S. 2009. Veterinary Diagnostic Imaging: Birds, Exotic Pets, and Wildlife. Mosby Elsevier, pp: 403-413.

Fossum, T.W. 2019. Small Animal Surgery, Fifth Edition. Elsevier, pp: 432-481; 365398.

Girolamo, N., Mans, C. 2016. Reptile Soft Tissue Surgery. Vet. Clin. Exot. Anim., 19, 97-131.

Guiffrida, M.A., Brown, D.C. 2018. In Tobias, K., Johnston, S. (2nd Edition). Veterinary Surgery: Small Animal. Saunders Elsevier, pp: 4003-4112.

Herrin, K.V. 2018. Clinical Technique and Suportive Care. In Doneley, B., Johnson, R., Monks, D., Carmel, B. Reptile Medicine and Surgery in Clinical Practice. Wiley Blackwell, pp: 159-174.

Klaphake, E., Gibbons, P.M., Sladky, K.K., Carpenter, J.W. 2018. Reptiles. In Carpenter, J.W., Marion, C.J. (5th Edition). Exotic Animal Formulary. Elsevier, pp: 125-247.

Knotek, Z., Wilkinson, S.L. 2018. Surgery. In Doneley, B., Johnson, R., Monks, D., Carmel, B. Reptile Medicine and Surgery in Clinical Practice. Wiley Blackwell, pp: 383396.

Kyles, A.E., Huck, J.L. 2018. Esophagus. In Tobias, K., Johnston, S. (2nd Edition). Veterinary Surgery: Small Animal. Saunders Elsevier, pp: 3888-4003.

Mader, D.R., Bennet, R.A., Funk, R.S., Fitzgerald, K.T., Vera, R., Hernandez-
Divers, S.J. 2006. Surgery. In Mader, D. (2nd Edition). Reptile Medicine and Surgery. Saunders Elsevier, pp: 581-630.

McArthur, S., Hernandez-Divers, S. 2004. Surgery. In McArthur, S., Wilkinson, R., Meyer, J. Medicine and Surgery of Tortoise. Blackwell Publishing, pp: 403-464.

Mitchell, M.A. 2006. Theraupetic. In Mader, D.R. (2nd Edition). Reptile Medicine and Surgery. Saunders Elsevier, pp: 631-664.

O’Malley, B. 2005. Clinical Anatomy and Physiology of Exotic Species. Saunders, Elsevier, pp: 40-45.

Perpinan, D. 2018. Reptile Anaesthesia and Analgesia. CPD Article-Companion Animal, April 2018, 23(4), 2-9.

Rodrigues, M.C., Lima, W.C., Quessada, A.M., Silva, F.A.N., Silva, L.M.C. de Souza, A.B., de Moura, C.R.C., Lima, D.A.S.D. 2015. Celiotomy by Platrotomy in Yello-Footed Tortoise (Geochelone denticulata). Pesq. Vet. Bras., 35(2), 173-176.

Rossi, J.V. 2006a. General Husbandry and Management. In Mader, D.R. (2nd Edition). Reptile Medicine and Surgery. Saunders Elsevier, pp: 25-41.

Rossi, J.V. 2006b. Turtle, Tortosies and Terrapins. In Mader, D.R. (2nd Edition). Reptile Medicine and Surgery. Saunders Elsevier, pp: 631-664.

Schumacher, J., Yelen, T. 2006. Anesthesia and Analgesia. In Mader, D.R. (2nd Edition). Reptile Medicine and Surgery. Saunders Elsevier, pp: 441-452.

Silverman, S. 2006. Diagnostic Imaging. In Mader, D.R. (2nd Edition). Reptile Medicine and Surgery. Saunders Elsevier, pp: 471489. 
UNEP-WCMC. 2014. Review of Stigmochelys pardalis from Mozambique and Zambia (Source F and R). [Technical Report]. UNEP-WCMC, Cambridge.

Yamgar, A.T., Lokhande, D.U., Yadav., Dakhne, P.S. 2019. Succesful Surgical Management of Foreign Body in Tortoise. Int. J. Curr.

Zaher, M., El-Ghareeb, A.W., Hamdi, H., Lahsik, S. 2012. Anatomical, Histological and Histochemical Adaptation of The Reptilian Alimentary Canal to Their Food Habits: 1. Uromastyx aegyptiaca. Life Sci. J., 9(3), 84-104.

Microbiol. App. Sci., 8(2), 922-926. 